\title{
THE DISRUPTION \\ OF THE 1940 AND 2020 TOKYO OLYMPICS: SPORTS DIPLOMACY DURING WAR AND PANDEMIC
}

\author{
Md Nasrudin Md Akhir ${ }^{1}$, Geetha Govindasamy ${ }^{2}$, Rohayati Paidi ${ }^{3}$
}

Sports diplomacy possesses the power to bring the best of the human spirit by affirming shared aspirations. Olympic Games share a similar propensity to bring people together across boundaries regardless of race, nationality, religion, income and country, reinforcing the true basis of sportsmanship and solidarity between all nations and spectators. The Tokyo Olympics, which were originally scheduled to take place in Japan in 1940, was cancelled due to the outbreak of World War Two. Likewise, the 2020 Olympic Games was postponed to 2021 due to the COVID-19 pandemic. While 80 years ago, amidst the war, Japan faced backlash before it cancelled the Olympic Games, the effect of the re-scheduled 2020 Olympics due to the COVID-19 pandemic demonstrates that such confrontational attitude has been replaced by understanding and solidarity from the global community of the consequences of hosting the games. Using a qualitative method, this article explores the differences in perceptions towards Japan during the 1940s which was overshadowed by war and the year 2020 which continues to be blanketed by the COVID-19 pandemic.

Keywords: Pandemic, Tokyo Olympics, sports diplomacy, war

\section{INTRODUCTION}

Sports diplomacy exhibits the extent to which states utilize sports to advance international and public diplomacy. Nixon's 1971 Ping-Pong diplomacy is one example how sports assisted in advancing international contacts between China and the US when formal diplomatic relations were non-existent. ${ }^{4}$ Similarly, in the present scenario, the Olympic Games have become the ultimate sports diplomacy tool, possessing profound capacity to bring people together across the globe regardless of race, nationality, religion, income or social status. The games are a medium where the true basis of sportsmanship and camaraderie is developed and reinforces the importance of solidarity as one of the fundamental and universal values that underscores ties between all nations, athletes and spectators. Japan has and continues to advance sports diplomacy via its involvement in hosting the 1964 and the postponed 2020 Olympic Games. While this is the case, sports

\footnotetext{
${ }^{1}$ Corresponding Author: An Associate Professor, Department of East Asian Studies, Faculty of Arts and Social Sciences, University of Malaya, Kuala Lumpur, Malaysia. Email: mnasrudi@um.edu.my

${ }^{2}$ Senior Lecturer, Department of East Asian Studies, Faculty of Arts and Social Sciences, University of Malaya, Kuala Lumpur, Malaysia. Email: geethag@um.edu.my

${ }^{3}$ Senior Lecturer at the Department of East Asian Studies, Faculty of Arts and Social Sciences, University of Malaya, Kuala Lumpur, Malaysia. Email: rohayatipaidi@um.edu.my

${ }^{4}$ Sayuri Guthrie-Shimizu, "Japan's Sports Diplomacy in the Early Post-Second World War Years," International Area Studies Review, Vol. 16, No. 3, 2013, p. 326.
} 
diplomacy also has a dark side whereby Japan had no option but to cancel the 1940 Tokyo Olympics due to adverse global perceptions towards the state. Regrettably, Japan was also debarred in the post war 1948 Olympic Games. Consequently, Japan used sports diplomacy as a tool to restore its international image by successfully hosting the 1964 Olympic Games. ${ }^{5}$

The Olympic Games have been cancelled three times since 1896: 1916 in Berlin, 1940 in Tokyo $^{6}$ and 1944 in London, following the outbreak of World War I (WWI) and World War II (WWII). The Tokyo Olympics was originally scheduled to take place in 1940 but was cancelled due to the outbreak of WWII. Japan was given the honour of hosting again in 1964. Similarly, the Olympic Games that had been scheduled for 2020 had to be postponed between July 23 and August 8, 2021 due to the global coronavirus disease 2019 (COVID-19) pandemic. While the effects of the postponement of the Olympics during the war was a very different scenario than during COVID-19, it did demonstrate a strong solidarity of all participating countries to find ways so that the games could be participated in safety by many countries, regardless of ideology, economic blocs or status. The cancellation and postponement of the two instances of the games was made due to the safety factor of the athletes, contingents and spectators based on the consideration that if the games were continued, it would certainly not be well received by majority of the participating countries. Japan has had no choice but to postpone the 2020 Tokyo Olympics - this postponement is the first incident in the history of the Olympics. ${ }^{7}$

Japan has tried to host the Olympic Games on twelve occasions, winning the bid five times; this included the 1940 games that were cancelled as well as the 2020 games that was postponed. This means that Japan has essentially been bidding, lobbying, campaigning, preparing for, and has been financially capable of hosting the Olympic Games almost constantly since 1932. The specific reasons behind Japan's persistent interest in hosting the supreme mega-sports event are multifaceted and closely linked to the state's changing roles in the international and regional geopolitical arenas. It is important to understand both the historical significance of the Olympics and their potential to serve as a catalyst for change in the future. ${ }^{8}$ There is no denying that the Olympics are capable of stimulating the economy leading to the growth of the host country. This article analyses the disruption of the Olympic Games in 1940 which was caused by WWII and the year 2020 as a consequence of COVID-19 using a qualitative research method.

\section{JAPAN'S EARLY ENGAGEMENT IN SPORTS DIPLOMACY}

On November 25, 1892, during the 5th anniversary of the Union of French Societies of Athletic Sports (USFSA in French), Pierre de Coubertin, a French educator proposed the reinstatement of the Olympic Games. ${ }^{9}$ Accordingly, the International Olympic Committee (IOC) was established on June 23, 1894 as the principal outcome of an international congress convened in Paris. Believing that sporting events are the initiator for global solidarity, unity and peace. Coubertin,

\footnotetext{
5 Jessamyn R. Abel, “Japan's Sporting Diplomacy: The 1964 Tokyo Olympiad,” The International History Review, Vol. 34, No. 2, June 2012, p. 203.

${ }^{6} 1940$ Olympics to be Staged in Tokyo, Morning Tribune, 3 August, 1936.

${ }^{7}$ Barbara Holthus, Isaac Gagné, Wolfram Manzenreiter, and Franz Waldenberger (Eds.), Japan Through the Lens of the Tokyo Olympics, London: Routledge, 2020, p. xvii.

${ }^{8}$ Robin Kietlinski, "Japan in the Olympics, the Olympics in Japan," Education About ASIA, Vol. 21, No. 2, Fall 2016, p. 35.

9 Patrick Clastres, "Playing with Greece. Pierre de Coubertin and the Motherland of Humanities and Olympics," Histoire@ Politique. Politique, culture, société, No. 12, September-December 2010, p. 3.
} 
the founder of the IOC, nurtured sports and humanitarian relations to achieve these goals. ${ }^{10}$ His aim included the rejuvenation of the Olympic Games by holding quadrennial celebrations and his dream was first realised in 1896, in Athens.

In 1909 Auguste Gérard, the French ambassador to Japan, was requested by Coubertin to invite Jigorō Kanō to become the first-ever Japanese member of the IOC. ${ }^{11} \mathrm{Kanō}$ was a key figure in the development of physical education in Japanese institutions. As the principal of the Tokyo Higher Normal School (forerunner of the Tsukuba University), he made great efforts to promote jūdō, a form of unarmed combat that combines elements of samurai jüjutsu with techniques meant to promote the traditional martial art into domestic and international arenas. ${ }^{12}$

A martial art of Japanese society, jūdō was developed and implemented as a form of education aimed at strengthening moral, physical and spiritual attributes of the Japanese. In the early stages of the modern Olympics however, which had been rebranded by Coubertin, jūdō faced the challenge of being accepted by Western powers as one of the competing events at the Olympics. ${ }^{13}$ Although the image of jūdō is directly linked to Japanese traditions, it has bridged the gaps between generations spanning Eastern and Western cultures. The image of Kano's method stands out as unique as jūdō has steadily combined education and competition with traditions and modernity. Therefore, the acceptance of jūdō into the Olympics is a revealing sign of world recognition of Japan's sports diplomacy right from the beginning. ${ }^{14}$ At the same time, it reflects the acceptance of a Japanese individual's involvement in the Olympics.

Indeed, Kanō was very much concerned with advancing Japan's physical education which was in vogue in the West at that time. The argument was that physical education strengthened one's body as well as individual ethics and values. The morals and lessons learned through modern sports, not only jūdō, could be applied to the daily lives of Japanese. As the President of the IOC when Kanō was advocating sports for Japan, Coubertin also believed in athletics for social reforms. ${ }^{15}$ Hence, this friendship marked the beginning of Japan entering into the Olympics. In keeping with Coubertin's demand that the Olympic Games be open to all nations and nationalities, Kanō thus became the first appointed IOC member from Asia. It was mainly European and American competitors from some 25 nations that participated regularly in the Olympics without any Asian presence whatsoever at that time. ${ }^{16}$ Kanō later established the Japan Sports Association (JSPO) in 1911 as an initial means of preparation for participation in the Olympics. In 1910, the IOC formally invited Japan to take part in the 5th Olympiad, scheduled to be held in Stockholm, Sweden in 1912. ${ }^{17}$

10 The IOC Annual Report 2019: Credibility, Sustainability, Youth, Lausanne: International Olympic Committee, 2020 , p. 5.

${ }^{11}$ Brian Watson, "Jigoro Kano and the Olympics", Kano Society Bulletin, Issue No. 43, April 2020, p. 1.

${ }^{12}$ Robin Kietlinski, "Japan in the Olympics, the Olympics in Japan', Education About ASIA, Vol. 21, No. 2, Fall 2016, p. 36.

${ }^{13}$ Andreas Niehaus, 'Spreading Olympism and the Olympic Movement in Japan: Interpreting "Universal” Values,' in William W. Kelly and Susan Brownell (Eds.), The Olympics in East Asia: Nationalism, Regionalism, and Globalism on the Center Stage of World Sports, New Haven: Yale University, 2011, p. 77.

${ }^{14}$ Michel Brousse, Judo/Influence of Jigoro Kano in the Global Education and the Olympic Movement, December 2018, available at: http://michelbrousse.fr/wp-content/uploads/2018/12/Judo-and-OlympicsTsukuba.pdf, accessed on 15 February, 2021.

${ }^{15}$ Robin Kietlinski, “Japan in the Olympics, the Olympics in Japan', Education About ASIA, Vol. 21, No. 2, Fall 2016, p. 36 .

${ }_{16}$ Brian Watson, "Jigoro Kano and the Olympics", Kano Society Bulletin, No. 43, April 2020, p. 1.

${ }^{17}$ Robin Kietlinski, "Japan in the Olympics, the Olympics in Japan,” Education About ASIA, Vol. 21, No. 2, Fall 2016, p. 36 . 
The strong backing by Coubertin to break the Western-centrism of the Olympics increasingly gained support as Japan steadily positioned itself internationally as well as strengthened its national identity. However, consideration for the acceptance of sports originating from Asia into the Olympics, including jūdō, was not something that was easily accepted. In fact, the attempt to overcome a Western hegemony in the Olympics by adding "a little bit of Asia" deviates from the real goals and aspirations of Olympism itself. ${ }^{18}$ According to Coubertin, "Olympism is not a system; it is a state of mind. It can accommodate the most widely divergent approaches, and no race or time can hold an exclusive monopoly". ${ }^{19}$ However, at that time in Japan, few people viewed the Olympics, still a junior event, as politically or strategically important enough to warrant Japanese participation. This was evident when Kanō failed to obtain financial sponsorships to cover athletes' travel costs for the $1912,5^{\text {th }}$ Olympiad. The disappointment led Kanō to form his own association, the Dai Nippon Taiiku Kyōkai (Greater Japan Physical Education Association), of which he became the President. ${ }^{20}$ With the involvement of Kanō, the Japanese Olympic Committee (JOC) was established in $1911 .{ }^{21} \mathrm{He}$ organised an Olympic qualifying competition that same year, where Yahiko Mishima, a short distance runner from the Imperial University and Shiso Kanaguri, a marathoner of the Tokyo Higher Normal School qualified for the $5^{\text {th }}$ Olympiad, the first games in which Japan took part at the Olympics. ${ }^{22}$ Given his strong leadership and determination, Kanō is therefore considered the "father of the Olympic Movement" in Japan. ${ }^{23}$

Though the Olympic Games were to be held in Berlin in 1916, they were cancelled due to WWI. While participating in the 1920 Olympics in Antwerp, Belgium, Japan sent 15 athletes and won two silver medals in singles and doubles tennis. ${ }^{24}$ Between 1912 and 1930, the need to participate at the Olympic Games were gaining ground in Japan. At the Belgian Olympics, Japanese teams were awarded their very first two gold medals in the triple jump and swimming events in Amsterdam, Netherlands in $1928 .{ }^{25}$ Besides the Olympics, according to a report by Kanō, dated August 1, 1921 that was sent to Coubertin, President of the IOC, the Far Eastern Championship Games event was to be held in Shanghai, China in the same year. It is interesting to note that Kanō did mention in his report that, "Efforts will be made to induce other nations in Asia including Siam, Malaya, Java, India and Ceylon to send at least a few representatives each to the next Championship Games."26

\footnotetext{
${ }^{18}$ Andreas Niehaus, 'Spreading Olympism and the Olympic Movement in Japan: Interpreting "Universal" Values,' in William W. Kelly and Susan Brownell (Eds.), The Olympics in East Asia: Nationalism, Regionalism, and Globalism on the Center Stage of World Sports, New Haven: Yale University, 2011, pp. 87-88.

${ }^{19}$ Andreas Niehaus, "Spreading Olympism and the Olympic Movement in Japan: Interpreting "Universal" Values," in William W. Kelly and Susan Brownell (Eds.), The Olympics in East Asia: Nationalism, Regionalism, and Globalism on the Center Stage of World Sports, New Haven: Yale University, 2011, p. 75.

${ }^{20}$ Robin Kietlinski, "Japan in the Olympics, the Olympics in Japan', Education About ASIA, Vol. 21, No. 2, Fall 2016, p. 36 .

${ }^{21}$ From Martial Art to Olympic Sport - PART 1, available at: https://www.ijf.org/history/from-martial-art-to-olympicsport/1051., accessed on 24 January, 2021.

${ }^{22}$ Sandra Collins, The 1940 Tokyo Games: The Missing Olympics- Japan, the Asian Olympics and the Olympic Movement, London: Routledge, 2007, p. 9.

${ }^{23}$ About the Olympic Games, available at: https://tokyo2020.org/en/games/olympic-games-about/, accessed on 24 January, 2021.

${ }^{24}$ From Martial Art to Olympic Sport - PART 1, available at: https://www.ijf.org/history/from-martial-art-to-olympicsport/1051., accessed on 24 January, 2021.

${ }^{25}$ Brian N. Watson, "Jigoro Kano and the Olympics", Kano Society Bulletin, Issue No. 43, April 2020, p. 2.

${ }^{26}$ Brian N. Watson, “Jigoro Kano’s Voyages”, Kano Society Bulletin, Issue No. 43, April 2020, p. 6.
} 
In the first Olympic Games held after WWII in London in 1948, Japan was excluded from participating in the Olympics just like Germany and Italy. Like many European cities involved in the war, London was no exception to the challenge of recovering and it had to use most of the existing facilities given the limited time to host an event with all-new infrastructure facilities. ${ }^{27}$ After being readmitted to the IOC in 1951, Japan dispatched a team of 72 athletes to the 1952 Olympics in Helsinki. Additionally, Japan made a bid to the IOC for Tokyo to host the 17th Olympiad that was to be held in 1960, but failed as Rome was selected instead. In 1960, Japan dispatched 167 athletes to take part in the $17^{\text {th }}$ Olympics. After failing to host the 1940 Olympics, Japan began a campaign to gain support in organising the 1964 Olympics, but faced two potential competitors from Detroit and Vienna. Japan's dream was finally fulfilled when the OIC delegates voted on March 26, 1960 and side-lined the two rivals. ${ }^{28}$

Undoubtedly, the reconstruction of the country after WWII as well as the encouraging performance of economic growth since the late 1950s proved that the organisation of the 18th Olympic Games in Tokyo in October 1964 was a historic moment for Japan. Japan's determination to host the 1964 Olympics succeeded in transforming Tokyo into a metropolis and was even more meaningful as jūdō managed to get included in the Olympics. ${ }^{29}$ The Olympics became the key element of a national economic strategy to double the gross domestic product (GDP) per head in a decade, and the resultant urban planning transformed Tokyo to its present status. The games initiated the comprehensive rebuilding of the city's sewage system; the construction of expressways; new subway lines; a hyper-modern and efficient public transport system, port and airport; as well as the Shinkansen linking Tokyo and Osaka. ${ }^{30}$

While there are parallels between Tokyo's Olympic bids for the 1940 and 1964 games in that both times the nation wished to portray the event as an opportunity to highlight their equality with advanced Western nations, other objectives underlying the two bids were quite different. In the 1930s, Japan used the Olympics to emphasise that it was more advanced than the rest of Asia and should therefore expand its sphere of regional influence. The 1964 Tokyo Olympics assured the world that Japan had re-emerged as a peaceful and economically successful nation, and proved that the state remained strong and intact in spite of the devastation and loss incurred during WWII. Therefore, the 1964 Olympics is frequently referenced in narratives in relation to how quickly and successfully Japan grew after the war. ${ }^{31}$

There is no denying that the success of hosting the 1964 Olympic Games, which was the first in Asia, became the starting point in framing a positive narrative that Japan is a new global economic powerhouse. Failure to host the 1940 Olympics as a result of its involvement in WWII as well as being excluded from participating in the 1948 London Olympics, was redeemed in 1964 after rising to economic glory during the Cold War era. The Olympics were not the only impetus that pushed Japan back into the international community, but its determination to reject the war and lead to a peace-loving nation succeeded in making Japan the second strongest economic power

\footnotetext{
27 Cydney Grannan, 7 Significant Political Events at the Olympic Games, available at, https://www.britannica.com/list/7-significant-political-events-at-the-olympic-games, accessed on 3 February, 2021.

28 Japan and the Olympics: Asia's first Olympic host, Japan Fact Sheet, p. 2, available at: https://webjapan.org/factsheet/en/pdf/18Olympics.pdf., accessed on January 26, 2021.

${ }^{29}$ Ibid, p. 3, accessed on 12 February, 2021.

${ }^{30}$ David Goldblatt, The Games: A Global History of the Olympics, New York: W. W. Norton \& Company, 2018, pp. 205-206.

${ }^{31}$ Robin Kietlinski, "Japan in the Olympics, the Olympics in Japan', Education About ASIA, Vol. 21, No. 2, Fall 2016, p. 38 .
} 
in the world until $2010 .{ }^{32}$ After being accepted as the 80th member of the United Nations on December 18, 1956, Japan began to actively seek membership in international sports organizations. Thus, the 1964 Tokyo Olympics were built upon the foundation of the cessation of war and aggression between nations and the tragedy and bitterness of military invasion and colonisation. ${ }^{33}$

\section{THE CANCELLATION OF THE 1940 TOKYO OLYMPICS}

On September 1, 1923, the Great Kanto earthquake occurred which was the strongest natural disaster ever to be recorded in Japan. But seven years later, Tokyo celebrated with a reconstruction festival in March 1930 to recognise the success of the redevelopment of the city with modern infrastructure. ${ }^{34}$ According to David Goldblatt, Tokyo officials originally touted a bid for the 1940 Olympics as a way to showcase the recuperation from the devastating 1923 earthquake and recovery from the resultant economic slowdown of the 1929 Great Depression. Hidejirō Nagata, who took office as the Mayor of Tokyo in May 1930, planned the re-development of Tokyo to become a more strategic and vibrant city. In order to position itself on a more equal footing with powerful Western nations such as England, France, Germany and United States, Japan set its sights on hosting the 1940 Olympics as it was the year that coincided with the 2,600th anniversary of the founding of the country. ${ }^{35}$ It is believed that Emperor Jimmu established the country in 660 BCE. ${ }^{36}$ Nagata recognised the economic and political importance of 1940 as a key milestone and therefore promoted the Tokyo Olympics to attract economic opportunities as well as visitors to the newly reconstructed modern capital. ${ }^{37}$ As a result, just prior to the opening of the 10th Olympic Games in Los Angeles in 1932, Nagata approached Kanō and urged him to take steps to make the 1940 Tokyo Olympics a reality. ${ }^{38}$

Other than Tokyo, eight other cities attempted to host the Olympic Games in 1940 Alexandria, Barcelona, Buenos Aires, Dublin, Helsinki, Rio de Janerio, Rome and Toronto were all vying for the honour. ${ }^{39}$ Nagata soon became absorbed with the idea of combining the imperial festival with a bid to host the 1940 Tokyo Olympics. Kanō, who had high hopes of bringing the Olympics to Asia for the first time stated, "I carry a grave resolve. The Olympics should naturally

\footnotetext{
${ }^{32}$ Christian Tagsold, 'The Tokyo Olympics: Politics and Aftermath,' in William W. Kelly and Susan Brownell (eds.), The Olympics in East Asia: Nationalism, Regionalism, and Globalism on the Center Stage of World Sports, New Haven, Connecticut: Yale CEAS Occasional Publication Series, 2011, p. 63.

${ }^{33}$ Shimizu Satoshi, 'Rebuilding the Japanese Nation at the 1964 Tokyo Olympics: The Torch Relay in Okinawa and Tokyo,' in William W. Kelly and Susan Brownell (eds.), The Olympics in East Asia: Nationalism, Regionalism, and Globalism on the Center Stage of World Sports, New Haven, Connecticut: Yale CEAS Occasional Publication Series, 2011, p. 41.

${ }^{34}$ Sandra Collins, The 1940 Tokyo Games: The Missing Olympics- Japan, the Asian Olympics and the Olympic Movement, London: Routledge, 2007, p. 23.

${ }^{35}$ Robin Kietlinski, "Japan in the Olympics, the Olympics in Japan," Education About ASIA, Vol. 21, No. 2, Fall 2016, p. 37.

36 Asato Ikeda, "The Tokyo Olympics: 1940/2020," The Asia-Pacific Journal, Volume 18, No. 4, 2020, p. 4.

${ }^{37}$ Sandra Collins, The 1940 Tokyo Games: The Missing Olympics - Japan, the Asian Olympics and the Olympic Movement, London: Routledge, 2007, pp. 23-24.

${ }^{38}$ Report of the Organizing Committee on Its Work for the XIIth Olympic Games of 1940 in Tokyo Until the Relinquishment, Tokyo: The Organizing Committee of the XIIth Olympiad, 1940, p. 2; Brian Watson, "Jigoro Kano and the Olympics", Kano Society Bulletin, Issue No. 43, April 2020, p. 2.

${ }^{39}$ Brian Watson, "Jigoro Kano and the Olympics", Kano Society Bulletin, Issue No. 43, April 2020, pp. 2-3.
} 
come to Japan. If they don't, the reason for this must be something unjust". ${ }^{40}$ Although internally, the Japanese IOC committee members did not show positive support for the games due to differing interests amongst sportsmen and politicians, nonetheless, Japan's surprising success in the 1932 Los Angeles Olympics proved to showcase a positive international image of the country. ${ }^{41}$ Furthermore, it was a reality that the Manchurian crisis in 1931 equally did not affect Japan's attempts to host the Olympics.

At the $35^{\text {th }}$ IOC Session meeting held in Berlin in 1936, a final vote was called for between the two remaining candidate cities: Helsinki and Tokyo. ${ }^{42}$ Japan finally managed to gain the IOC's trust to host the 12th Olympic Games in 1940 on July 31, 1936, one day before Hitler officially officiated the Berlin Olympics. ${ }^{43}$ News of Japan's success in being selected to host the Olympic Games in Tokyo received international media coverage, including the Malay Tribune in Malaya. ${ }^{44}$ The initial meeting of the organising committee for the 1940 Tokyo Olympics was held on December 14, 1936 where Prince Iyesato Tokugawa was elected as its President. The meeting was also attended by Torataro Ushizuka, Mayor of Tokyo, Matahiko Oshima, President of the National Olympic Committee of Japan as well as Kanō, the IOC member. ${ }^{45}$ From 1936 to 1938, there were altogether 27 meetings to discuss the games that took place with the last meeting held on June 10, $1938 .{ }^{46}$

Preparations for organising the Tokyo Olympics began as early as December 1936. Accordingly, the Engineering Bureau of the Ministry of Communications began upgrading the telegraph and telephone communications infrastructure to achieve international and domestic efficiency. The key plan for regional and international broadcasting had six divisions; namely; Europe; North and South America; Extreme Orient; Siam, Straits Settlements, Philippines; Australia, New Zealand; and India, speaking in Japanese, English, French, German, Russian, Spanish, Italian as well as the languages of Peking, Fukien, Canton, Siam, Annan, Malay, and Burma. ${ }^{47}$ As communications were very limited to disseminate information and attain a wider circulation in the 1930s, various methods were utilised to publicise the Olympic Games. For instance, Japanese who were travelling abroad on some special occasions were requested to spread information overseas. Masao Kume, who was sent to England to broadcast for Japan on the occasion of the Coronation was among the early individuals sent abroad. Led by Sadakichi Hitotsumatsu, a Japanese Diet member, seven other members left for the International Parliamentary Conference in August 1937. Meanwhile, Shingoro Takaishi, Takuo Godo, Kishichiro Okura, Kojiro Matsukata, Bunji Suzuki, Kikujiro Ishii, Shiro Machida, and Hitoshi Ashida left Japan in October 1937 as Japanese envoys to various countries for the publicity of the

40 The Games that became the Missing Olympics, The Hindu, 17 March, 2020, available at: https://www.thehindu.com/sport/other-sports/the-games-that-became-the-missing-olympics/article31092514.ece, accessed on 10 February, 2021.

${ }^{41}$ William W. Kelly, "(Book review) Sandra Collins, The 1940 Tokyo Games: The Missing Olympics-Japan, the Asian Olympics and the Olympic Movement, London: Routledge, 2007," Journal of Japanese Studies, Vol. 36, No. 2, 2010, p. 426.

${ }^{42}$ Brian Watson, "Jigoro Kano and the Olympics", Kano Society Bulletin, No. 43, April 2020, p. 3.

${ }^{43}$ Torsten Weber, 'Tokyo's 1940 "Phantom Olympics" in Public Memory when Japan Chose War over the Olympics,' in Barbara Holthus, Isaac Gagné, Wolfram Manzenreiter, and Franz Waldenberger (Eds.), Japan Through the Lens of the Tokyo Olympics, Routledge: London, 2020, p. 67.

${ }_{44} 1940$ Olympics to be Staged in Tokyo, Malaya Tribune, 1 August, 1936, p. 14.

${ }^{45}$ Report of the Organizing Committee on Its Work for the XIIth Olympic Games of 1940 in Tokyo Until the Relinquishment, Tokyo: The Organizing Committee of the XIIth Olympiad, 1940, p. 2.

${ }^{46}$ Ibid, p. 2.

${ }^{47}$ Ibid. p. 98. 
12th Olympic Games. ${ }^{48}$ The Japanese private mail steamship company, Nippon Yusen Kaisha (NYK) took the initiative to publicise the games by providing passengers with envelopes imprinted "XII OLYMPIAD/TOKYO 1940" in two diagonal lines and on the reverse an imprint of the N.Y.K insignia. ${ }^{49}$

In terms of ground transportation, especially trains and subways, the construction of new lines connecting the towns around Tokyo and its vicinity were expanded. For instance, a new line connecting the existing Odakyu line main route with a new station of Seijo Gakuen constructed. In addition to the Odakyu line, the Tokyo-Yokohama Electric Railway Company proposed the construction of a new route leading to the main entrance of the Komazawa Grounds. The Tokyo Rapid Transit Railway constructed a subway from Shimbashi to Shibuya connecting the TokyoYokohama line as part of the main route of the Tokyo train and subway network system. To increase efficiency and enhance services to be able to accommodate a greater passenger capacity of up to 100,000 people at a time, especially during peak hours, government-owned companies and private companies such as Meguro-Kamata Electric Line, Oimachi Line and the Tamagawa Electric Line were all involved in modernising the Japanese railway network systems. ${ }^{50}$

However, internationally, the Asia-Pacific region was fraught with tensions between many powers including China and Japan in the middle of the 1930s. Consequently, with the outbreak of the Sino-Japanese War on July 7, 1937, it quickly became clear that the war would not be over within weeks or months. Against this backdrop, international pressure began to emerge towards Japan due to this crisis. The Japanese Foreign Ministry received a message from Henri de BailletLatour, the President of the OIC, that there was a possibility the international community would boycott the games in Japan. ${ }^{51}$ Avery Brundage, president of the American Amatuer Athletic Union (AAU), who was one of the delegates to the IOC meeting in Cairo, disclosed that the IOC contemplated holding the 1940 Olympic Games on a modified basis elsewhere if for any reason Tokyo decided to give them up. ${ }^{52}$ Faced with the increasingly turbulent instability of world security, the possibility of continuing to organise the Olympic Games as planned was increasingly questioned by many in power, thus forcing the relocation of the venue for the games. However, at the $37^{\text {th }}$ IOC Cairo meeting in March 1938, Japanese delegates provided reassurances that Tokyo remained steadfast and had no intention of withdrawing from hosting the Olympics. ${ }^{53}$ There were also claims that there was an implicit intent of Japanese policymakers to make the success of organising the Olympics as a means to further nurture Japanese relations with major world powers in the West. ${ }^{54}$ Due to the Manchurian crisis, the Japanese image took a severe beating. The Manchurian incident created backlash from Western democratic nations resulting in Japan leaving the League of Nations in 1933. Consequently, there was diplomatic pressure on other countries to

\footnotetext{
48 Ibid, p. 112.

${ }^{49}$ Torch Bearer: 1940 Tokyo: The Games of the XIIth Olympiad, Great Britain: Society of Olympic Collectors, 2007, p. 7 .

50 Report of the Organizing Committee on Its Work for the XIIth Olympic Games of 1940 in Tokyo Until the Relinquishment, Tokyo: The Organizing Committee of the XIIth Olympiad, 1940, p. 97.

51 Torsten Weber, 'Tokyo's 1940 “Phantom Olympics” in Public Memory when Japan Chose War over the Olympics,' in Barbara Holthus, Isaac Gagné, Wolfram Manzenreiter, and Franz Waldenberger (eds.), Japan Through the Lens of the Tokyo Olympics, London: Routledge, 2020, p. 69.

${ }^{52}$ Olympics May yet be Transferred, Morning Tribune, 30 May, 1938.

${ }^{53}$ Kumiharu Shigehara, On Arguments for the Cancellation of the 2020 Olympic Games in Tokyo, Tokyo, 5 August, 2017, available at: http://office.shigehara.online.fr/en/articles/NK2.pdf, accessed on 12 January, 2021.

54 Tokyo 1940: The Missing Olympics, The Economic Times, 17 March, 2020, available at: https://economictimes.indiatimes.com/news/sports/tokyo-1940-the-missing-

olympics/articleshow/74680638.cms?from=mdr, accessed on 1 February, 2021.
} 
host the 1940 Olympics. Amidst this backdrop, Japanese diplomats abroad via cables alerted Tokyo that major powers such as Britain and the United States could boycott the games. ${ }^{55}$

Even within Japanese policy makers, there were calls to concede the hosting of the Olympics. As early as 1937, shortly after the outbreak of the China-Japan War, Ichiro Kono, a member of the Diet, called for the hosting of the Olympics to be reconsidered due to domestic and regional instability. Nonetheless, political leaders, as well as members of the Japanese IOC committee insisted on continuing, despite knowing even the 1938 Far Eastern Games had been canceled. They were of the opinion that the Japan-China war would soon be over. However, the war with China in 1937 strained Japan's relationship with its Western Allies. Understanding that there might be a boycott of the games, the Japanese government not only cancelled the 1940 Olympics but also postponed the Tokyo exhibition. ${ }^{56}$ The Marquis Kido, Minister for Public Welfare, a member of the Japanese government, commented on the cancellation as follows:

The unavoidable cancellation of the 12th Olympic Games Tokyo is indeed deeply regretted. As the year for the Olympic Games would have coincided with the celebration for the 2600th anniversary of the founding of the Japanese Empire, and also because it would afford a wonderful opportunity to introduce our national status to the world, the people of Japan, as a whole, has placed high hopes on the Games. ${ }^{57}$

The total budget for the 12th Olympic Games, which was planned to be held in Tokyo 1940, was set for 20,142,427.00 yen, of which, 12,920,277.00 yen was to be defrayed by the Organizing Committee, while the balance of 7,222,200.00 yen was to be derived from other sources ${ }^{58}$ Overall, the cancellation of the 1940 Olympic Games coincided with Japanese political regional power ambitions. As a consequence, starting with the Sino-Japanese war and internal calls for investing more in the military, the prospect for Japan hosting the games diminished as time passed. Furthermore, the reaction from the major powers like Britain and the United States to the growing Japanese regional political expansion resulted in the country being viewed negatively. Therefore, it is not surprising that the Japanese government eventually cancelled the 1940 games so as not to face a boycott which would have been further detrimental to the Japanese image.

\section{THE 2020 TOKYO OLYMPICS}

During an official gathering marking the 100th anniversary of the JOC and the JSPO, Shintaro Ishihara, governor of Tokyo on July 16, 2011 announced the city's candidacy for hosting the 2020 Olympics. ${ }^{59}$ After two rounds of voting during the 125th IOC Session held in Buenos Aires, Tokyo managed to get the highest number of votes by 60 compared to Istanbul which only managed to get 36 votes. Accordingly, the OIC announced on September 7, 2013 that it awarded the right to

\footnotetext{
55 Tokyo 1940: The Games that Became the Missing Olympics, Bangkok Post, 17 March, 2020, available at: https://www.bangkokpost.com/world/1880650/tokyo-1940-the-games-that-became-the-missing-olympics, accessed on 1 February, 2021.

56 Asato Ikeda, "The Tokyo Olympics: 1940/2020," The Asia-Pacific Journal, Vol. 18, No. 4, 2020 , p. 4.

57 Report of the Organizing Committee on Its Work for the XIIth Olympic Games of 1940 in Tokyo Until the Relinquishment, Tokyo: The Organizing Committee of the XIIth Olympiad, 1940, pp. 121-122.

${ }^{58}$ Ibid, p. 124.

59 Japan announces bid to stage 2020 Olympic Games, CNN, 11 July, 2011, available at: http://edition.cnn.com/2011/SPORT/07/16/japan.olympics/index.html, accessed on 13 February, 2021.
} 
organise the 32nd Olympic Games to Tokyo. ${ }^{60}$ With the 2020 Olympics as the focal point, Japan planned on showcasing its economic affluence, cultural assets, technological advances, and social stability to dispel the notion that it has faded as an international power. ${ }^{61}$ At the same time, there are claims that Japan wanted to take the opportunity to use the 2020 Olympics to prove that it hadprincipa recovered from the catastrophic earthquake, tsunami, and Fukushima Daiichi nuclear crisis that caused Japan significant devastation in March 2011. ${ }^{62}$ In any case, the fact is that any country may have the desire to showcase something great, the best and admired while being given the right to host any mega-event globally. Despite the failure of Japan's bid for the 2016 Olympics in 2009, even if Tokyo had succeeded in its bid, the three great disasters were so destructive that they would have made it difficult in hosting the Olympics. Undeniably, the 2011 tragedy that claimed nearly 20,000 lives, devastated the economy worth about 16.9 trillion yen and destroyed 404,937 homes has left a deep trauma to this day. ${ }^{63}$ Based on previous nuclear incidents, it is expected that recovery will take between 20-30 years to be restored. ${ }^{64}$ Naoki Inose, the governor of Tokyo had a similar view when linking the Olympics to the 2011 tragedy. He once stated that, "The earthquake and tsunami of March 2011 deeply affected the Japanese people, and we are in need of a dream we can share that will strengthen our solidarity. A dream can give us strength, and with strength we can build a future." He further added that Japan could "demonstrate to the world how far we have come in rebuilding our country, and give courage especially to those who are confronted with a challenge of hardship." 65

There is no denying that Japan, the first host of the Olympic Games in Asia, has shown remarkable success, and the success of hosting the second Olympics will definitely raise a sense of pride among the Japanese. Even the success of athletes in winning gold medals and even more so in athletes who break new world records will be upheld and always be admired. Thus, it can be said that the Olympic Games are a very meaningful arena to celebrate success and express pride at national and international levels. ${ }^{66}$ Until the end of March 2020, official data released by the organisers showed that a total of 206 nations would be competing in 339 sports events. In addition, there were 42 sites throughout Japan that had been selected as competition venues and the Tokyo Olympics were expected to host more than 11,000 athletes. ${ }^{67}$ In addition to athletes, the number

\footnotetext{
${ }^{60}$ Kumiharu Shigehara, On Arguments for the Cancellation of the 2020 Olympic Games in Tokyo, 5 August, 2017, available at: http://office.shigehara.online.fr/en/articles/NK2.pdf, accessed on 12 January, 2021.

${ }^{61}$ Kiyoteru Tsutsui, Japan's Three Most Consequential Events of 2020, Nikkei Asia, 28 December, 2020, available at: https://asia.nikkei.com/Opinion/Japan-s-three-most-consequential-events-of-2020, accessed on 19 February, 2021.

62 The Games that Became the Missing Olympics, The Hindu, 17 March, 2020, available at: https://www.thehindu.com/sport/other-sports/the-games-that-became-the-missing-olympics/article31092514.ece, accessed on 10 February, 2021.

${ }^{63}$ Shinji Nakahara and Masao Ichikawa, "Mortality in the 2011 Tsunami in Japan," Journal of Epidemiol, Vol. 23, No. 1, 2013, p. 70; Donican Lam, A Decade on, Japan Remembers Those Lost in Deadly Quake and Tsunami," The Japan Times, 11 March, 2021, available at: https://www.japantimes.co.jp/news/2021/03/11/national/japan-10-yearsdisaster/, accessed on March 14, 2021.

${ }^{64}$ Jules Boykoff and Christopher Gaffney, "The Tokyo 2020 Games and the End of Olympic History," Capitalism Nature Socialism, 2020, Vol. 31, No. 2, p. 3.

${ }^{65} \mathrm{Ibid}, \mathrm{p} .4$.

${ }^{66}$ Shimizu Satoshi, 'Rebuilding the Japanese Nation at the 1964 Tokyo Olympics: The Torch Relay in Okinawa and Tokyo,' in William W. Kelly and Susan Brownell (Eds.), The Olympics in East Asia: Nationalism, Regionalism, and Globalism on the Center Stage of World Sports, New Haven, Connecticut: Yale CEAS Occasional Publication Series, 2011, p. 40.

${ }^{67}$ Ruruku Imahashi and Francesca Regalado, Olympics Delay to Cost Japan \$6bn in Economic Losses, Nikkei Asia, 24 March, 2020, available at: https://asia.nikkei.com/Spotlight/Tokyo-2020-Olympics/Olympics-delay-to-cost-Japan6bn-in-economic-losses, accessed on 18 February, 2021.
} 
of participating officers from all competing nations was estimated at more than 7,000 who were also joined by about 25,000 media personnel, and more than 110,000 volunteers from all over the world. ${ }^{68}$ It was also reported that the Japanese fans had already purchased almost 4.5 million of the 7.8 million total tickets. Japanese stakeholders spent between US $\$ 12.6$ to US $\$ 25.2$ billion and the National Broadcasting Company (NBC) had fulfilled its commitment amounting to US\$1.4 billion for the American broadcast alone. ${ }^{69}$

The Games are an energetic event in the global ultra-modern city, along with the constellation of ideas and applications associated with the pursuit of a global futuristic city like Tokyo. ${ }^{70}$ Organising the Olympics not only showcases the capabilities of a city with various attractions, but Tokyo will be the focus with the latest telecommunications and technological advancements. The Olympic Games attract interest among social media, sponsorships, as well as licensing and ticketing revenues on a scale unimaginable, even more after the introduction of 5G technology and multimedia. ${ }^{71}$ The Olympics are not just about sport, but serve to highlight and showcase the greatness of telecommunications as well as the latest technological infrastructure that all lead to a more prosperous and peaceful life..$^{72}$

The increasing number of cities bidding to host the Olympics as well as the huge funds allotted in bidding for the games indicate that states perceive securing such an event serves as an opportunity to improve the economic and social aspects of a particular city or state through the multiple effects of macroeconomic chains. For example, the cost of planning, hiring consultants, organising events, and necessary travel consistently falls between US\$50 million and US\$100 million. Tokyo spent as much as US $\$ 150$ million on its failed 2016 Olympics bid, and about US\$75 million for 2020 to be successful. ${ }^{73}$ Apparently, the countries that once hosted the Olympics recorded positive side effects on socio-economic growth; this led to an increasing number of countries bidding for the Olympics. ${ }^{74}$

Table 1 shows the initial estimated cost verses the actual spending of the Olympic Games by cities around the world from 1976 to 2016. It shows that the 1984 Los Angeles Olympics and the 1996 Atlanta Olympics had the lowest actual spending in the history of the Olympic games over the last 40 years. The United States managed to optimise the cost of the organising of the games in the most cost-effective way and it was similar to what Britain had done by using existing facilities while hosting the 1948 Olympics due to the time constraints along the way of recovering from the war. Therefore, the US has proven that, having too superficial ambitions to host the Olympics is impractical in economic terms.

\footnotetext{
68 Volunteers for the Tokyo 2020, Tokyo Metropolitan Volunteerism Navigation Website, available at: https://www.cityvolunteer.metro.tokyo.lg.jp/en/about/tokyo2020/volunteers/index.html\#: :text=the\%20Olympic\%20Village„How\%20many,Expect\%2080\%2C000\%20Games\%20Volunteers, accessed on February 18, 2021.

${ }^{69}$ Helen Macnaughtan, "Japan, the Olympics and the COVID-19 Pandemic," East Asia Forum, 23rd June, 2020 , p. 2.

${ }^{70}$ John R. Short, "Globalization, cities and the Summer Olympics," City, Vol. 12, No. 3, 2008, p. 323.

${ }^{71}$ Richard W. Pound, 'On Security and Surveillance in the Olympics: A View from Inside the Tent,' in Vida Bajc (Ed.), Surveilling and Securing the Olympics from Tokyo 1964 to London 2012 and Beyond, London: Palgrave Macmillan, 2016, p. 72.

72 About the Olympic Games, available at: https://tokyo2020.org/en/games/olympic-games-about/, accessed on 3 February, 2021.

73 James McBride, The Economics of Hosting the Olympic Games, Council on Foreign Relations, 19 January, 2018, available at: https://www.cfr.org/backgrounder/economics-hosting-olympic-games, accessed on 15 February, 2021.

${ }^{74}$ Maximos Malfas, Eleni Theodorak and Barrie Houlihan, "Impacts of the Olympic Games as Mega-Events," Municipal Engineer, Vol. 157, No. 3, January 2004, p. 209.
} 
Table 1: Olympic Cost Overruns

$\begin{array}{lll}\text { Year } & \text { Venue } & \text { Initial Estimate } \\ 1976 & \text { Montreal } & \text { \$74 million } \\ 1980 & \text { Moscow } & \mathrm{n} / \mathrm{a} \\ 1984 & \text { Los Angeles } & \text { \$333 million } \\ 1988 & \text { Seoul } & \text { \$2.3 billion } \\ 1992 & \text { Barcelona } & \text { na } \\ 1996 & \text { Atlanta } & \text { \$400 million } \\ 2000 & \text { Sydney } & \text { \$895 million } \\ 2004 & \text { Athens } & \text { \$ 5.5 billion } \\ 2008 & \text { Beijing } & \text { \$14.2 billion } \\ 2012 & \text { London } & \text { \$5.9 billion } \\ 2016 & \text { Rio de Janeiro } \$ 14 \text { billion }\end{array}$

Actual Spending

$\$ 1.1$ billion

$\$ 3.0$ billion

$\$ 97$ million

$\$ 2.7$ billion

$\$ 2.1$ billion

$\$ 503$ million

$\$ 1.1$ billion

$\$ 16$ billion

$\$ 40$ billion

$\$ 18$ billion

\$20 billion

(current estimate)

Note: $\mathrm{n} / \mathrm{a}$ - not available

\begin{abstract}
Source: John R. Short, "Globalization, Cities and the Summer Olympics," City, Vol. 12, No. 3, 2008, p. 335; James McBride, The Economics of Hosting the Olympic Games, Council on Foreign Relations, January 19, 2018 (https://www.cfr.org/backgrounder/economics-hosting-olympic-games)
\end{abstract}

The results of previous research show mixed findings as to whether the hosting of the Olympic Games leads to a positive economic stimulus effect or vice versa on the host country. For instance, Mitsuhiro Osada quoted a research finding by Rose and Spiegel who claimed that host countries' real exports significantly increased and argued that this may be related to the implementation policies by the host countries to increase their openness around the time they were chosen to host the games. Osada took the Japanese example of engaging in negotiations for the Trans-Pacific Partnership (TPP) in 2013, when it was chosen to host the Olympics. ${ }^{75}$ However, many others have found that hosting such supreme mega-events may lead to a short-term increase temporarily, especially in tourism and trade. In fact, there is mixed evidence to prove that tourism is increased over the long-term in relation to the improvement of hotels, tourist attraction spots and infrastructure facilities. In fact, in the case of air transport services for example, although the frequency of flights will increase many times before and during the Olympic Games, the inbound visitors to the host country does not necessarily remain high after the Olympics. Being host for the Olympic Games is unlikely to gain a nation much more beyond prestige. However, from a strategic perspective, the objectives may include highlighting or spotlighting a city or nation, attracting investment, or creating jobs. Among these, the economic value that could potentially accrue to the city or country is the most commonly used rationale for gathering public backing for these events. ${ }^{76}$

\footnotetext{
75 Mitsuhiro Osada, Mayumi Ojima, Yoshiyuki Kurachi, Ko Miura \& Takuji Kawamoto, "Economic Impact of the Tokyo 2020 Olympic Games," BOJ Reports \& Research Papers, January 2016, p. 4.

${ }^{76}$ Carroll Howard Griffin, "Mega-Event Sporting Opportunities: The Case of Developed vs. Developing Countries," The Journal of International Management Studies, Vol. 10, No. 2, August 2015, pp. 16-17.
} 


\section{COVID-19 AND THE UNCERTAINTY OF THE 2020 TOKYO OLYMPICS}

While all final preparations to host the Tokyo Olympics were on the way, China however, reported the discovery of a new disease on December 31, 2019. Two weeks later on January 13, 2020, officials from the World Health Organisation (WHO) confirmed a case of COVID-19 in Thailand, the first recorded case outside of China. ${ }^{77}$ Japan, on the other hand, recorded the first COVID-19 case on January 16, 2020, which was a cause for concern as the date for the July 2020 Olympics was so close. The virus was spreading at a very rapid rate due to the infinite global movement of travellers resulting in uncontrolled large-scale pandemics. By March 15, 2020, COVID-19 cases in China alone were recorded at 81,048 and the total worldwide cases were reported at 153,517 according to the WHO. ${ }^{78}$ The surge in COVID-19 cases that had increased drastically all over the world led many countries to announce lockdowns as a precautionary measure and speculations grew about a delay or cancellation of the Olympics. Finally, on March 24, 2020, the Japanese government officially announced that the Olympics were postponed for one year. This was the first time in the history of the Olympics that the sport has been postponed due to a pandemic. ${ }^{79}$ Eventually, a joint statement by the IOC and the Tokyo 2020 Organising Committee on March 24, 2020 declared that, "... in the present circumstances and based on the information provided by the WHO, the IOC president and the Prime Minister of Japan have concluded that the games in Tokyo must be rescheduled to a date beyond 2020 but not later than summer 2021, to safeguard the health of the athletes, everybody involved in the Olympic Games and the international community." 80

From end of March 2020 onwards there was an unbelievable surge in the number of patients infected with COVID-19; this caused the Japanese government to declare a state of emergency on April 7, 2020 in some parts of the country. ${ }^{81}$ Somewhat surprisingly before the postponement announcement, the number of cases reported did not grow exponentially in Japan as it did in Western Europe and the U.S. Initially, there were claims that the Japanese government was manipulating the numbers to leave open the possibility for the Olympics to take place. Soon after, the dominant narrative was that long-standing hygiene practices of wearing face masks and washing hands in Japan were the main reasons for the lower number of cases compared to other advanced nations. ${ }^{82}$

Containing the pandemic was crucial as Japan is eager to host the Olympics, even when it became postponed to July 2021. Yoshihide Suga, the Prime Minister of Japan remarked he was determined to hold a safe Olympic Games by implementing all possible preventive measures and hoped the games would serve as a springboard for recovery of an economy battered by the

\footnotetext{
${ }^{77}$ Archived: WHO Timeline - COVID-19, 27 April, 2020, available at: https://www.who.int/news/item/27-04-2020who-timeline---covid-19, accessed on 19 February, 2021.

78 Coronavirus disease 2019 (COVID-19) Situation Report - 55, 15 March, 2020, available at: https://www.who.int/docs/default-source/coronaviruse/situation-reports/20200315-sitrep-55-covid-19.pdf, accessed on 16 February, 2021.

${ }^{79}$ Helen Macnaughtan, "Japan, the Olympics and the COVID-19 Pandemic," East Asia Forum, 23rd June, 2020, p. 1.

${ }^{80}$ Olympics: Japan PM Shinzo Abe, IOC Agree to Delay Tokyo Olympics by One Year, The Straits Times, 24 March 2020, available at: https://www.straitstimes.com/sport/olympics-japan-will-hold-olympics-by-summer-2021-atlatest-pm-shinzo-abe-says, accessed on 1 March, 2021.

${ }^{81}$ Eiji Yamamura and Yoshiro Tsutsui, "The Impact of Postponing 2020 Tokyo Olympics on the Happiness of OMO-TE-NA-SHI Workers in Tourism: A Consequence of COVID-19," Sustainability, 2020, 12, p. 3.

${ }^{82}$ Kiyoteru Tsutsui, Japan's Three Most Consequential Events of 2020, Nikkei Asia, 8 January, 2020, available at: https://asia.nikkei.com/Opinion/Japan-s-three-most-consequential-events-of-2020, accessed on 28 December, 2020.
} 
pandemic. ${ }^{83}$ Until December 2020, the Tokyo Olympics were projected to cost 1.35 trillion yen and the Tokyo Organizing Committee estimated that the yearlong delay would result in an additional 294 billion yen in costs, including for wages and pandemic response measures. ${ }^{84}$

Since Athens Olympics in 1896, the games have been a glorious global sporting event that has always been eagerly awaited among multiracial trans-boundary spectators. The Olympics bring together the largest human gathering to a host city that also exhibits economic spillover in various sectors, all wrapped up in one intense, colorful, and often controversial extravaganza. ${ }^{85}$ For the 2020 Tokyo Olympics, the organisers stated that the Tokyo 1964 Games completely transformed Japan, enhanced the image of the Japanese internationally and stimulated rapid growth in Japan's economy. ${ }^{86}$ The Tokyo Olympics of 1964 ushered in Japan's miracle years of economic growth and rejuvenation following the catastrophe of WWII. ${ }^{87}$ While, the postponed 2020 Tokyo Olympics is expected to enable Japan as a mature economy to promote future changes throughout the world and leave a positive legacy for future generations. ${ }^{88}$ However, the impact of COVID-19 has massive economic implications for Japan beyond Tokyo 2020. The investment in facilities and infrastructure will likely pay off for Tokyo over time, particularly given current decisions on sustainability. ${ }^{89}$ Investments in the media industry and advertising agencies for example has reached millions of dollars, and the risk was huge in the uncertainty of whether the games will really be held. However, on March 21, 2021, the Japanese government decided that the games will go on without overseas spectators. ${ }^{90}$

Unlike the cancellation of the Tokyo Olympics in 1940 due to WWII, the delay of the 2020 games was inevitable due to the global pandemic. The joint initiative to combat the pandemic has become a global effort. Yoshihide Suga, Prime Minister of Japan on January 18, 2021 vowed to forge ahead with plans despite mounting public opposition in Japan. ${ }^{91}$ The challenge is whether enough athletes and countries are able to participate and really make the games a reality. It is still not clear how traveling and border restrictions may hinder participation of athletes as international borders are largely impassable. ${ }^{92}$ Nonetheless, the Japanese government has barred overseas spectators to the games.

\footnotetext{
${ }^{83}$ Yukio Tajima, Suga Vows to Crush Virus with Potent Dose of Law and Vaccine, Nikkei Asia, 8 January, 2021, available at: https://asia.nikkei.com/Spotlight/Coronavirus/Suga-vows-to-crush-virus-with-potent-dose-of-law-andvaccine, accessed on 10 January, 2021.

${ }^{84}$ Tokyo Olympics Secure \$200m in Sponsor Money to Cover Delay, Nikkei Asia, 12 December, 2020, available at: https://asia.nikkei.com/Spotlight/Tokyo-2020-Olympics/Tokyo-Olympics-secure-200m-in-sponsor-money-to-coverdelay, accessed on 17 January, 2021.

${ }_{85}$ William W. Kelly, Preface, in William W. Kelly and Susan Brownell (Eds.), The Olympics in East Asia: Nationalism, Regionalism, and Globalism on the Center Stage of World Sports, New Haven: Yale University, 2011, p. 1.

${ }^{86}$ Robin Kietlinski, "Japan in the Olympics, the Olympics in Japan," Education About ASIA, Vol. 21, No. 2, Fall 2016, p. 35 .

${ }^{87}$ Helen Macnaughtan, "Japan, the Olympics and the COVID-19 Pandemic," East Asia Forum, 23 June, 2020, p. 2.

${ }^{88}$ Robin Kietlinski, "Japan in the Olympics, the Olympics in Japan," Education About ASIA, Vol. 21, No. 2, Fall 2016, p. 35.

${ }^{89}$ Helen Macnaughtan, "Japan, the Olympics and the COVID-19 Pandemic," East Asia Forum, 23 June, 2020, p. 2.

${ }^{90}$ Unavoidable': Overseas Fans Barred from Tokyo Olympics over Virus, Japan Times, 21 March, 2021, available at: https://www.japantimes.co.jp/news/2021/03/21/national/olympics-spectators-meeting-2/, accessed on 23 March, 2021.

${ }^{91}$ OLYMPICS/ London 2012 Chief Feels Tokyo Games Unlikely to Go Ahead, The Asahi Shimbun, 20 January, 2021, available at: http://www.asahi.com/ajw/articles/14121618, accessed on 27 March, 2021.

92 Dan Roan, Tokyo Olympics 'Unlikely to Go Ahead in 2021', BBC News, 20 January, 2021, available at: https://www.bbc.com/news/business-55722542, accessed on 29 January, 2021.
} 
Therein lies an asymmetry in the benefits of holding the Olympics versus the cost of not holding them. ${ }^{93}$ In the past, the Olympic Games have never been canceled for any public health reasons. ${ }^{94}$ A cancellation, even a partial one, would result in significant monetary damage for many parties involved. Television stations have already set broadcasting schedules and big sponsor companies have purchased commercial spots. Postponement is estimated to cost an additional US $\$ 2.7$ to US\$5.8 billion for Japan, while complete cancellation is estimated to be a loss of US $\$ 41.5$ billion. ${ }^{95}$ In sum, a postponement may be an easier route to take, but this too, would require huge added costs in terms of both monetary implications and human resources repercussions. ${ }^{96}$ At the time of writing, it appears that the games will go on as scheduled albeit with some modifications. Given this, Tokyo will be able to minimise its losses.

\section{CONCLUSION}

Sports has proven capable of mobilising and expressing powerful national patriotism as well as bringing the entire world together in peaceful competition. Moreover, the Olympic Games have not only provided shared cultural experiences but have also promoted positive images of the host city and country. While the economic benefits in terms of attracting new businesses and investments cannot be denied, for Japan, sports diplomacy in the form of the Olympic Games, especially the 1964 Tokyo Olympiad allowed it to re-engage with the international community more confidently. It is not too much to claim that Japan views the Olympic Games as an asset to advance its image abroad as past memories continue to disrupt Japanese global efforts somewhat. As the Diplomatic Bluebook 2018 indicates,

MOFA and the Japan Foundation (JF) implement various projects, through introducing Japanese culture and sports overseas, to create positive images of Japan in foreign countries, boost the value of brands in Japan while encouraging deeper understanding of Japan, and foster individuals and groups knowledgeable about Japan for the future. ${ }^{97}$

Nonetheless, historical and health developments both internally and externally have twice affected Japan's quest to host the Olympics. Japan is the only country globally to experience two disruptions of the Olympics, firstly in 1940 due to the outbreak of WWII and secondly in 2020 following the emergence of the COVID-19 pandemic. For both of these disruptions, Japan has paid a hefty price in terms of costs. The world is in the midst of an unprecedented global crisis due to COVID-19. At this exceptional moment in world history, the IOC and the entire Olympic Movement stand together in solidarity with all of society in the fight to contain it. Despite such a stance, mass gathering events have the potential to spread infectious diseases. Therefore, the

\footnotetext{
${ }^{93}$ Ryusei Takahashi, Tokyo Olympics in the Balance as COVID-19 Surges Around World, The Japan Times, 19 November, 2020, available at: https://www.japantimes.co.jp/news/2020/11/19/national/social-issues/tokyo-olympicscoronavirus-global-surge/, accessed on 29 January, 2021.

${ }^{94}$ Eiji Yamamura and Yoshiro Tsutsui, "The Impact of Postponing 2020 Tokyo Olympics on the Happiness of OMO-TE-NA-SHI Workers in Tourism: A Consequence of COVID-19," Sustainability, 2020, 12, p. 1.

${ }^{95}$ Helen Macnaughtan, "Japan, the Olympics and the COVID-19 Pandemic," East Asia Forum, 23 rd June, 2020, p. 2.

96 Tokyo 2020 Olympics: Trump Says Delaying Olympics a Year Better Than No Spectators, Nikkei Asia, 13 March 2020, available at: https://asia.nikkei.com/Spotlight/Tokyo-2020-Olympics/Trump-says-delaying-Olympics-a-yearbetter-than-no-spectators, accessed on 29 January, 2021.

${ }_{97}$ Diplomatic Bluebook 2018, Tokyo: Ministry of Foreign Affairs, Japan, 2019, p. 349
} 
argument that the Olympics should be postponed in order to safeguard athletes from such health consequences is convincing. Nonetheless, the 2020 Tokyo Olympics is now set to be held between July 23 and August 8, 2021 followed by the Paralympics from August 24 to September 5, 2021. In the midst of an unprecedented global crisis that has impacted the world, the Olympic Games are expected to play an important and complimentary role in global socio-economic recovery efforts.

However, it has to be noted that the Olympic Games hold potential significant health and socioeconomic risks for the host country population as well as visitors to Tokyo during and after the games. The decision to bar overseas spectators is in line with the notion that the event may not be able to safely accommodate a huge number of spectators to Japan. Limiting fans is the best assurance against a public health disaster. Thus far, the IOC and Tokyo organisers have come up with rules and regulations to be followed including a 14-day quarantine period for athletes before their arrival in Tokyo. ${ }^{98}$ According to Angela Rasmussen, a virologist from Georgetown University, the best course of action Tokyo organisers can undertake now is to require everyone involved in the games to be vaccinated. According to her,

Letting in a huge influx of people, many from countries with out-of-control coronavirus transmission, is in fact a threat to the public health of the Japanese people, she said. I don't think it would be ethically problematic to require everyone to be vaccinated - it's a public health issue and it is a private event. It might be challenging, as the access and availability varies from country to country, and it would have to be done with enough time for athletes to potentially receive both doses, but that might be the safest option for Japan. ${ }^{99}$

With the world facing over 126,359,540 confirmed positive cases and 2,769,473 deaths globally as of March 28, 2021, ${ }^{100}$ and though vaccines are now available, with new virus strains, it is difficult to predict the extent to which the available vaccines can mitigate another potential outbreak of COVID-19. Despite this, the games will be held with overseas spectators banned, for the first time in Olympic history. Against this backdrop, to promote sports diplomacy, everyone is duty bound to support the Japanese decision so as not to give space to another Olympic-sized outbreak during the games.

\footnotetext{
98 Ayai Tomisawa and Yuki Hagiwara, Doubts Loom Over Tokyo Olympics Without Vaccine, Isolation Rules, Bloomberg, 4 February, 2021, available at: https://www.bloomberg.com/news/articles/2021-02-03/questions-hangover-tokyo-olympics-even-after-playbook-unveiled, accessed on March 10, 2021.

${ }_{99}$ D'Arcy Maine, Are the Tokyo Olympics really going to happen? ESPN.Com, 18 February, 2021, available at: https://www.espn.com/olympics/story/_/id/30861660/are-tokyo-olympics-really-going-happen, accessed on 23 February, 2021.

100 World Health Organization (WHO), COVID-19 Weekly Epidemiological Update, WHO, 28 February, 2021, available at: https://covid19.who.int/, accessed on 1 March, 2021.
} 


\section{REFERENCES}

1940 Olympics to be Staged in Tokyo, Malaya Tribune, 1 August, 1936.

1940 Tokyo: The Games of the XIIth Olympiad, Torch Bearer, 2007.

About the Olympic Games, available at: https://tokyo2020.org/en/games/olympic-games-about/, accessed on 24 January, 2021.

Andreas Niehaus, 'Spreading Olympism and the Olympic Movement in Japan: Interpreting "Universal" Values,' in William W. Kelly and Susan Brownell (Eds.), The Olympics in East Asia: Nationalism, Regionalism, and Globalism on the Center Stage of World Sports, New Haven: Yale University, 2011, pp. 75-94.

Archived: WHO Timeline - COVID-19, 27 April, 2020, available at: https://www.who.int/news/item/27-04-2020-who-timeline---covid-19, accessed on 19 February, 2021.

Asato Ikeda, “The Tokyo Olympics: 1940/2020," The Asia-Pacific Journal, Vol. 18, No. 4, 2020, pp. 1-7

Barbara Holthus, Isaac Gagné, Wolfram Manzenreiter, and Franz Waldenberger (Eds.), Japan Through the Lens of the Tokyo Olympics, London: Routledge, 2020.

Brian N. Watson, “Jigoro Kano’s Voyages”, Kano Society Bulletin, No. 43, April 2020, pp. 4-7.

Carroll Howard Griffin, "Mega-Event Sporting Opportunities: The Case of Developed vs. Developing Countries," The Journal of International Management Studies, Vol. 10, No. 2, August 2015, pp. 15-26.

Christian Tagsold, 'The Tokyo Olympics: Politics and Aftermath,' in William W. Kelly and Susan Brownell (eds.), The Olympics in East Asia: Nationalism, Regionalism, and Globalism on the Center Stage of World Sports, New Haven, Connecticut: Yale CEAS Occasional Publication Series, 2011, pp. 61-74.

Coronavirus disease 2019 (COVID-19) Situation Report - 55, 15 March, 2020, available at: https://www.who.int/docs/default-source/coronaviruse/situation-reports/20200315-sitrep-55covid-19.pdf, accessed on 16 February, 2021.

Cydney Grannan, 7 Significant Political Events at the Olympic Games, available at, https://www.britannica.com/list/7-significant-political-events-at-the-olympic-games, accessed on 3 February, 2021. 
Dan Roan, Tokyo Olympics 'Unlikely to Go Ahead in 2021', BBC News, 20 January, 2021, available at: https://www.bbc.com/news/business-55722542, accessed on 29 January, 2021.

David Goldblatt, The Games: A Global History of the Olympics, New York: W. W. Norton \& Company, 2018.

Diplomatic Bluebook 2018, Tokyo: Ministry of Foreign Affairs, Japan, 2019.

Donican Lam, A Decade on, Japan Remembers Those Lost in Deadly Quake and Tsunami, The Japan Times, 11 March, 2021, available at: https://www.japantimes.co.jp/news/2021/03/11/national/japan-10-years-disaster/, accessed on March 14, 2021.

Eiji Yamamura and Yoshiro Tsutsui, "The Impact of Postponing 2020 Tokyo Olympics on the Happiness of O-MO-TE-NA-SHI Workers in Tourism: A Consequence of COVID-19," Sustainability, 2020, 12, pp. 1-16.

From Martial Art to Olympic Sport - PART 1, available at: https://www.ijf.org/history/frommartial-art-to-olympic-sport/1051., accessed on 24 January, 2021.

Helen Macnaughtan, "Japan, the Olympics and the COVID-19 Pandemic," East Asia Forum, 23rd June, 2020.

James McBride, The Economics of Hosting the Olympic Games, Council on Foreign Relations, 19 January, 2018, available at: https://www.cfr.org/backgrounder/economics-hosting-olympicgames, accessed on 15 February, 2021.

Japan and the Olympics: Asia's First Olympic Host, Japan Fact Sheet, p. 2, available at: https://web-japan.org/factsheet/en/pdf/18Olympics.pdf., accessed on January 26, 2021.

Japan announces bid to stage 2020 Olympic Games, CNN, 11 July, 2011, available at: http://edition.cnn.com/2011/SPORT/07/16/japan.olympics/index.html, accessed on 13 February, 2021.

Jessamyn R. Abel, "Japan's Sporting Diplomacy: The 1964 Tokyo Olympiad," The International History Review, Vol. 34, No. 2, June 2012, pp. 203-220.

John R. Short, "Globalization, cities and the Summer Olympics," City, Vol. 12, No. 3, 2008, pp. 321-340.

Jules Boykoff and Christopher Gaffney, "The Tokyo 2020 Games and the End of Olympic History," Capitalism Nature Socialism, 2020, Vol. 31, No. 2, pp. 1-19.

Kiyoteru Tsutsui, Japan's Three Most Consequential Events of 2020, Nikkei Asia, 28 December, 2020, available at: https://asia.nikkei.com/Opinion/Japan-s-three-most-consequential-events-of2020, accessed on 19 February, 2021. 
Kumiharu Shigehara, On Arguments for the Cancellation of the 2020 Olympic Games in Tokyo, Tokyo, 5 August, 2017, available at: http://office.shigehara.online.fr/en/articles/NK2.pdf, accessed on 12 January, 2021.

Maximos Malfas, Eleni Theodorak and Barrie Houlihan, "Impacts of the Olympic Games as MegaEvents," Municipal Engineer, Vol. 157, No. 3, January 2004, pp. 209-220.

Michel Brousse, Judo/Influence of Jigoro Kano in the Global Education and the Olympic Movement, December 2018, available at: http://michelbrousse.fr/wpcontent/uploads/2018/12/Judo-and-Olympics-Tsukuba.pdf, accessed on 15 February, 2021.

Mitsuhiro Osada, Mayumi Ojima, Yoshiyuki Kurachi, et all., "Economic Impact of the Tokyo 2020 Olympic Games,” BOJ Reports \& Research Papers, January 2016, pp. 1-21.

Olympics May yet be Transferred, Morning Tribune, 30 May, 1938.

Olympics: Japan PM Shinzo Abe, IOC Agree to Delay Tokyo Olympics by One Year, The Straits Times, 24 March 2020, available at: https://www.straitstimes.com/sport/olympics-japan-willhold-olympics-by-summer-2021-at-latest-pm-shinzo-abe-says, accessed on 1 March, 2021.

OLYMPICS/ London 2012 Chief Feels Tokyo Games Unlikely to Go Ahead, The Asahi Shimbun, 20 January, 2021, available at: http://www.asahi.com/ajw/articles/14121618, accessed on 27 March, 2021

Patrick Clastres, "Playing with Greece. Pierre de Coubertin and the Motherland of Humanities and Olympics," Histoire@Politique. Politique, culture, société, Vol. 3, No. 12, 2010, pp. 1-9.

Report of the Organizing Committee on Its Work for the XIIth Olympic Games of 1940 in Tokyo Until the Relinquishment, Tokyo: The Organizing Committee of the XIIth Olympiad, 1940.

Richard W. Pound, 'On Security and Surveillance in the Olympics: A View from Inside the Tent,' in Vida Bajc (Ed.), Surveilling and Securing the Olympics from Tokyo 1964 to London 2012 and Beyond, London: Palgrave Macmillan, 2016, pp. 72-92.

Robin Kietlinski, "Japan in the Olympics, the Olympics in Japan," Education About ASIA, Vol. 21, No. 2, Fall 2016, pp. 35-40.

Ruruku Imahashi and Francesca Regalado, Olympics Delay to Cost Japan \$6bn in Economic Losses, Nikkei Asia, 24 March, 2020, available at: https://asia.nikkei.com/Spotlight/Tokyo-2020Olympics/Olympics-delay-to-cost-Japan-6bn-in-economic-losses, accessed on 18 February, 2021.

Ryusei Takahashi, Tokyo Olympics in the Balance as COVID-19 Surges Around World, The Japan Times, 19 November, 2020, available at: https://www.japantimes.co.jp/news/2020/11/19/national/social-issues/tokyo-olympicscoronavirus-global-surge/, accessed on 29 January, 2021. 
Sandra Collins, The 1940 Tokyo Games: The Missing Olympics - Japan, the Asian Olympics and the Olympic Movement, London: Routledge, 2007.

Sayuri Guthrie-Shimizu, "Japan's Sports Diplomacy in the Early Post-Second World War Years," International Area Studies Review, Vol. 16, No. 3, 2013, pp. 325-335.

Shimizu Satoshi, 'Rebuilding the Japanese Nation at the 1964 Tokyo Olympics: The Torch Relay in Okinawa and Tokyo,' in William W. Kelly and Susan Brownell (eds.), The Olympics in East Asia: Nationalism, Regionalism, and Globalism on the Center Stage of World Sports, New Haven, Connecticut: Yale CEAS Occasional Publication Series, 2011.

Shinji Nakahara and Masao Ichikawa, "Mortality in the 2011 Tsunami in Japan," Journal of Epidemiol, Vol. 23, No. 1, 2013, pp. 70-73

The Games that became the Missing Olympics, The Hindu, 17 March, 2020, available at: https://www.thehindu.com/sport/other-sports/the-games-that-became-the-missingolympics/article31092514.ece, accessed on 10 February, 2021.

The IOC Annual Report 2019: Credibility, Sustainability, Youth, Lausanne: International Olympic Committee, 2020.

Tokyo 1940: The Games that Became the Missing Olympics, Bangkok Post, 17 March, 2020, available at: https://www.bangkokpost.com/world/1880650/tokyo-1940-the-games-that-becamethe-missing-olympics, accessed on 1 February, 2021.

Tokyo 1940: The Missing Olympics, The Economic Times, 17 March, 2020, available at: https://economictimes.indiatimes.com/news/sports/tokyo-1940-the-missing-

olympics/articleshow/74680638.cms?from=mdr, accessed on 1 February, 2021.

Tokyo 2020 Olympics: Trump Says Delaying Olympics a Year Better Than No Spectators, Nikkei Asia, 13 March 2020, available at: https://asia.nikkei.com/Spotlight/Tokyo-2020Olympics/Trump-says-delaying-Olympics-a-year-better-than-no-spectators, accessed on 29 January, 2021.

Tokyo Olympics Secure \$200m in Sponsor Money to Cover Delay, Nikkei Asia, 12 December, 2020, available at: https://asia.nikkei.com/Spotlight/Tokyo-2020-Olympics/Tokyo-Olympicssecure-200m-in-sponsor-money-to-cover-delay, accessed on 17 January, 2021.

Torch Bearer: 1940 Tokyo: The Games of the XIIth Olympiad, Great Britain: Society of Olympic Collectors, 2007.

Torsten Weber, 'Tokyo's 1940 "Phantom Olympics” in Public Memory when Japan Chose War over the Olympics,' in Barbara Holthus, Isaac Gagné, Wolfram Manzenreiter, and Franz Waldenberger (Eds.), Japan Through the Lens of the Tokyo Olympics, Routledge: London, 2020, pp. 66-72. 
Unavoidable': Overseas Fans Barred from Tokyo Olympics over Virus, Japan Times, 21 March, 2021, available at: https://www.japantimes.co.jp/news/2021/03/21/national/olympics-spectatorsmeeting-2/, accessed on 23 March, 2021.

Volunteers for the Tokyo 2020, Tokyo Metropolitan Volunteerism Navigation Website, available at: https://www.city-

volunteer.metro.tokyo.lg.jp/en/about/tokyo2020/volunteers/index.html\#: :text=the\%20Olympic \%20Village-,How\%20many,Expect\%2080\%2C000\%20Games\%20Volunteers, accessed on February 18, 2021.

William W. Kelly, "(Book review) Sandra Collins, The 1940 Tokyo Games: The Missing Olympics-Japan, the Asian Olympics and the Olympic Movement, London: Routledge, 2007," Journal of Japanese Studies, Vol. 36, No. 2, 2010, pp. 426-427.

William W. Kelly, Preface, in William W. Kelly and Susan Brownell (Eds.), The Olympics in East Asia: Nationalism, Regionalism, and Globalism on the Center Stage of World Sports, New Haven: Yale University, 2011, pp. 1-4.

Yukio Tajima, Suga Vows to Crush Virus with Potent Dose of Law and Vaccine, Nikkei Asia, 8 January, 2021, available at: https://asia.nikkei.com/Spotlight/Coronavirus/Suga-vows-to-crushvirus-with-potent-dose-of-law-and-vaccine, accessed on 10 January, 2021. 